ACTA UNIVERSITATIS LODZIENSIS

FOLIA LITTERARIA POLONICA 3(33) 2016

http://dx.doi.org/10.18778/1505-9057.33.07

Dorota Samborska-Kukuć*

\title{
Syndrom Charouska. Tomasza Judyma problemy z tożsamością
}

Wstrętne jest to, co zaburza tożsamość, system, ład.

Co nie przestrzega granic, miejsc, zasad. J. Kristeva, Potęa obrzydzenia. Esej o wstręcie

Moja nienawiść jest $\mathrm{z}$ tych, co idą poza grób, a jeszcze posiadam własną krew, którą wylać mogę, jak chcę - ażeby ta za jego krwią szła krok w krok do państwa cieni. G. Meyrink, Golem

Być może najbardziej spektakularną w literaturze niezgodę na ojca manifestuje samobójczym aktem bohater Meyrinkowskiego Golema, Innocenty (!) Charousek. Sprzeciw wobec dziedziczenia nienawistnej krwi wyraża widowiskową autoagresją - rezultatem narastającego wstrętu. Ojcem jego bowiem, ojcem dotychczas nieznanym, okazuje się budzący powszechną odrazę Żyd-tandeciarz, który uwiódłszy matkę Charouska, sprzedał ją do domu publicznego. Charousek jest owocem tego straszliwego związku1. Uświadomiwszy sobie (w dwójnasób, wszak Charousek studiuje medycynę) potworne dlań dziedzictwo, najpierw podstępnie organizuje zabójstwo ojca, następnie kładzie się na jego mogile i rozpruwa sobie tętnice tak, by krew wyciekała do grobu. Obrzydzenie i bunt wobec „siebie na podobieństwo ojca” nakazują mu zabić się w sposób symboliczny, rytualny (krew jako siła życiowa), pojmowany jako unicestwienie wstrętnego rodu $^{2}$. Samobójstwo Charouska jest nacechowane szczególnym masochizmem

* Dr hab., prof. UŁ, ddsk@wp.pl, Uniwersytet Łódzki, Instytut Filologii Polskiej, Katedra Literatury Pozytywizm i Młodej Polski, ul. Pomorska 171/173, 90-236 Łódź.

${ }^{1}$ Dyskusyjna jest jednowymiarowa interpretacja M. Mitchella (Vivo: The Life of Gustav Meyrink, Dedalus, Cambs 2008, s. 218), iż czyn Charouska ma jedynie wymiar zemsty, por. C.S. Gelbin, The Golem returns. From German romantic literature to global Jewish Culture 1808-2008, University of Michigan 2011, s. 103, 110.

${ }^{2}$ Zob. m.in. J. Tokarska-Bakir, Legendy o krwi. Antropologia przesadu, WAB, Warszawa 2008. 
i nienawiścią do siebie samego. To czyn niezrozumiały dla otoczenia, które zdolne jest jedynie w elementarnych zdaniach oznajmujących nazywać czynności i stawiać prostą diagnozę, bez wnikania w przyczyny i sens:

Straszny koniec zresztą sam sobie zrobił pan doktor Charousek. Sam sobie życie odebrał. Znaleziono go na grobie Arona Wassertruma. Leżał na piersiach. Wyrył dwie głębokie dziury w ziemi, tętnice sobie przeciął $\mathrm{i}$ wtedy ramiona włożył w dziury. Tak krew z niego wypłynęła. Zapewne był obłąkany pan doktor Charousek³.

Tak rozlicza się z ojcem-w-sobie protagonista Golema, dzieła wydanego piętnaście lat po ukazaniu się Ludzi bezdomnych, jednej z wielu powieści Stefana Żeromskiego, w której mowa jest o zmaganiu się z problemem tożsamości i samoakceptacji ${ }^{4}$. Pokazywana przez pisarza osobowość wywodzącego się z nizin inteligenta, Tomasza Judyma, rozchwiana jest wskutek samouświadomienia twardej determinacji dziedziczenia i wpływu środowiska, nasączenia patologią dysfunkcyjnej rodziny z proletariackiego dna, z szewskiej pracowni wiecznie cuchnącej wódką. Osobowość ta - jak słusznie zauważa Ewa Ihnatowicz - zaburzona jest wskutek ,żalu do losu za tak mizerne dzieciństwo, z tęsknoty do estetycznie i etycznie pojętego piękna w codzienności”’s. Judym dąży do wyzucia się z nienawistnych, budzących wstręt korzeni, które ciągną go w dół i nie pozwalają, jako moralnemu maksymaliście, żyć normalnym życiem. Zrozumienie okaleczenia pozwala mu na dostrzeżenie tej otwartej rany. Żeromski egzemplifikuje ją w akordzie końcowym poprzez symbol rozdartej sosny:

Widział z głębi swojego dołu jej pień rozszarpany, który ociekał krwawymi kroplami żywicy. Patrzał w to rozdarcie długo, bez przerwy. Widział każde włókno, każde ścięgno kory rozerwane i cierpiące ${ }^{6}$.

\footnotetext{
${ }^{3}$ G. Meyrink, Golem, przeł. A. Lange, Skład Główny w Księgarni F. Hoesicka, Warszawa 1919, s. 111.

${ }^{4}$ Postacią o podobnych, choć nie tak rzutujących na życie codzienne, problemach „rodowodowych" jest Andrzej Radek z Syzyfowych prac, pojawiający się także w Ludziach bezdomnych jako reminiscencja Judyma z czasów szkolnych (Radek był korepetytorem Judyma). Radek wstydzi się swojego wiejskiego pochodzenia i tego, że zanim Paluszkiewicz odkrył w nim materiał na intelektualistę, pasał świnie.

${ }^{5}$ E. Ihnatowicz, Bohaterowie polskiej prozy wspótczesnej 1864-1914. Artyści, twórcy, Wyd. Uniwersytetu Warszawskiego, 1999, s. 66.

${ }^{6}$ S. Żeromski, Ludzie bezdomni, oprac. I. Maciejewska, Zakład Narodowy im. Ossolińskich, Wrocław 1987, s. 406. Dalej skrótowa lokalizacja cytatów według tego wydania z podaniem numeru strony.
} 


\section{Rana po ojcu - studium DDA}

„Dla oznaczenia pewnego trudno objaśnialnego (a przecież powszechnego) fenomenu z psycho-socjologii zachowań inteligencji końca poprzedniego stulecia Stefan Żeromski wymyślił sobie termin: «ludzie bezdomni»" - pisał Andrzej Zieniewicz na marginesie rozważań o „tożsamości rozdwojonej” bohaterów prozy współczesnej. W jego szkicu pojawiła się także wzmianka o słynnej książce Janet K. Woititz, (D.D.A.) Doroste Dzieci Alkoholików, w której autorka próbuje łączyć psychiczne problemy osób mających smutne dzieciństwo z alkoholizmem rodziców jako jego dominantą ${ }^{8}$ Żeromski pojawia się w kontekście rozważań Zieniewicza wyłącznie jako twórca symbolicznej definicji wyobcowania wskutek doświadczeń z dzieciństwa. Tymczasem właśnie powieść Żeromskiego czytana według teorii Woititz odsłania i pozwala zrozumieć niektóre mechanizmy zachowań, a także uwarunkowania decyzji, jakie podejmuje protagonista $L u d z i$ bezdomnych. Mechanizmy te często sprawiały trudności interpretacyjne, bo nie dawało się ich wyjaśnić przez pryzmat li tylko ideowy, zaś stany psychiczne bohaterów werbalizowane były tylko częściowo9.

Nietrudno zauważyć, że zasadniczym problemem Judyma jest niemożność uwolnienia się od obciążeń bytujących w jego pamięci, która złośliwie, w sytuacjach najmniej temu sprzyjających, podsuwa bohaterowi wstrętny obraz ojca-alkoholika z nie mniej obrzydłym tłem: wiecznie chorą, bezwolną matką i ciotką prostytutką, za pieniądze której wykształcił się i został lekarzem. Wstręt do rodziny za to, że była taka, jaka była, i taka, jakby jej nie było, jest naturalną konsekwencją-dyspozycją pamięci ${ }^{10}$. Po każdym takim reminiscencyjnym seansie skonfrontowanym z teraźniejszością rodzi się w protagoniście dezaprobata podszyta gniewem i złością na przeszłość, której nie może zmienić, na swoją naturę, która - ukształtowana $\mathrm{w}$ tej przeszłości - zdradza rysy będące rysami ojca, na ograniczenia, które narzuca świadomość determinacji. Paradoksalnie przekleństwem Judyma jest jego emancypacja, wykroczenie poza klasę społeczną, z której się wywodzi, poza patologiczny świat gminu rządzony na przemian brutalną witalnością i śmiercią.

\footnotetext{
${ }^{7}$ A. Zieniewicz, Dorosłe Dzieci Epoki. Codzienność utajona w prozie lat dziewięćdziesiatych, w: Codzienne, przedmiotowe, cielesne. Języki nowej wrażliwości w literaturze polskiej XX wieku, red. H. Gosk, Świat Literacki, Izabelin 2002, s. 82-83.

8 J.K. Woititz, Dorosłe dzieci alkoholików, przeł. M. Winkler, Wydawnictwo Akuracik, Warszawa 1992. Autor pomylił książkę Janet Woititz z pracą Sharon Wegscheider-Cruse (Nowa szan$s a$, przeł. M. Ślósarska, Instytut Psychologii Zdrowia, Warszawa 2000), gdzie pojawia się przywołana przez niego znana typologia DDA. Cechy DDA zostały sformułowane w niniejszym artykule na podstawie dysertacji Woititz.

${ }^{9}$ Zob. S. Eile, Alogiczność i przypadek w prozie Żeromskiego, „Pamiętnik Literacki” 1976, z. 1, s. 6.

${ }^{10} \mathrm{O}$ takim zjawisku pisze J. Kristeva, Potęga obrzydzenia. Esej o wstręcie, przeł. M. Falski, Wydawnictwo Uniwersytetu Jagiellońskiego, Kraków 2007, s. 12.
} 
Wyobcowanie Judyma, tak charakterystyczne dla DDA, ma źródło w sprzeczności pomiędzy niskim pochodzeniem a wyuczoną profesją, która pozwoliła mu wejść po drabinie o kilka szczebli wyżej. Naiwnością bohatera jest jednak przekonanie, że przez tych, którym poprzysiągł wsparcie i pomoc, będzie traktowany jak swój. W rezultacie zabiegów zbliżenia się do biedoty, zamiast wdzięczności i zaufania otrzymuje niechęć i podejrzliwość. Jednym z objawów tej alienacji jest niemożność porozumienia się z bratem, Wiktorem, który traktuje Tomasza jak kogoś obcego, przybywającego z innego świata, na dodatek, pomijając realia wychowania w domu nierządu i szulerki, obarcza go winą za swój nędzny los, jakże odmienny teraz od losu tego drugiego.

Tomasz Judym nie chce być Tomaszem Judymem z ulicy Ciepłej. Gdy zachwyca go lub porusza jakiś przyjazny, wzbudzający przyjemne wrażenia fragment dookolnego świata (czemu służy charakterystyczna dla Ludzi bezdomnych psychizacja pejzażu), zaraz - jak widmo - zjawia się przeszłość:

[...] oto staje mu w oczach inny dom: suterena, wilgotny grób, pełen śmierdzącej pary. Ojciec wiecznie pijany, matka wiecznie chora. Zepsucie, nędza i śmierć... Co oni tam robili, czemuż mieszkali w jamie podziemnej, umyślnie zbudowanej na to, żeby hodować w ciele choroby, a w sercu nienawiść do świata?... (118)

Gdy chciałby miło spędzić czas w towarzystwie nowo poznanych pań i gdy już prawie wierzy w to, że - poprzez wykształcenie i obycie „parweniusza, który trafem stanął u drzwi pałacu kultury" (91) - może być im nawet równy, nadchodzi bolesna refleksja: diagnoza faktycznego położenia, w stawianiu której Judym jest dla siebie bezlitosny:

Judym czuł, że wtargnął do towarzystwa tych pań. Rozumiał swą niższość społeczną $\mathrm{i}$ to, że jest w tej samej chwili szewskim synem tudzież aspirantem do „towarzystwa”. Odróżniał w sobie te obydwie substancje i do krwi gryzł dolną wargę (18).

[...] piękne istoty nie przyjdą, że nie przyjdą dlatego mianowicie, że on ich oczekuje. On, Tomasz Judym, Tomek Judym z Ciepłej ulicy. Stał tak, patrząc na szarą, ciężką wodę i szeptał do siebie:

- Ulica Ciepła, ulica Ciepła...

Było mu nad wszelki wyraz głupio, jakoś niesmacznie i gorzko. W dalekim krańcu przelotnego wspomnienia snuł się obraz brudnej kamienicy... Podniósł głowę i otrząsnął się. [...] Tytuł gazety skojarzył się w umyśle Judyma z przeróżnymi myślami, w których szeregu błąkało się uprzykrzone, niemiłe, bolesne prawie pojęcie: ulica Ciepła, ulica Ciepła... O rodzinie swej, o warunkach, w jakich żywot jej upływa, myślał w owej chwili niby o czymś niezmiernie obcym, niby o typie pewnej familii małomieszczańskiej, która nędzną egzystencję swoją pędziła za panowania 
króla Jana Kazimierza. Te damy, które zobaczył dnia poprzedniego, stały się dlań tak szybko istotami bliskimi, siostrzanymi, przez wykwintność swych ciał, sukien, ruchów i mowy. Żal mu było, że nie przychodzą, i prawie nieznośnie na samą myśl, że mogą nie przyjść wcale. Jeżeli tak będzie, to dlatego, że z tych szewców wiedzie swój „rodowód...” (20-21).

[...] czym kiedy pomyślał o tym, jak należy się bawić? Grek połowę życia przepędzał na umiejętnej zabawie. Włoch średniowieczny udoskonalił sztukę próżnowania, to samo takie kobiety... Ja bym się zabawił na wycieczce, ale z kim? Z kobietami mego stanu, z jakimiś, przypuszczam, pannami „miastowymi”, ze studentkami, z białogłowami jednym słowem, co się nazywa. Ale z tymi! To jest tak jakby wiek dziewiętnasty, podczas kiedy ja żyję jeszcze z prapradziadkami na początku osiemnastego. Nie posiadam sztuki rozmawiania, zupełnie jakby pisarz prowentowy chciał układać dialogi a'la Lukian dlatego, że umie pisać piórem... Nie bawiłbym się, tylko bym dbał, żeby nie zrobić czegoś z szewska. Może to i lepiej... Ach, jak to dziwnie... Każda z tych bab tak jakoś żywo interesuje człowieka, każda, nawet ta stara, to istota nowoczesna, wyobrazicielka tego, co tytułujemy kulturą. A ja, cóż ja... szewczyna... (21).

Nie akceptując swoich korzeni i nie mogąc ich odciąć, wlecze się przez życie z balastem, który go przytłacza. Z drugiej strony jego dojrzewająca samoświadomość i normy etyczne modelują zachowania, które można by uznać za objaw wysublimowanego misjonarstwa: Judym chce wypłacić się światu za możliwość uniezależnienia się od najszerzej pojętej patrii potestatis i chce czynić to jako lekarz, uzdrowiciel-społecznik (,Będzie tu siał, będzie pracował za tłum ludzi, będzie oddawał światu wszystko, co wziął od niego. Nie pożałuje ramion, nie będzie skąpił potu! Niechże wiedzą, jak się wywdzięcza ten z motłochu, kogo przyjmą do swej kultury, komu udzielą cząsteczki swych praw do czynu"; 126). Niestety, mimo najlepszych chęci, nigdzie nie może zagrzać miejsca, co jest jak najbardziej znamienne dla syndromu DDA.

Typowym objawem syndromu Dorosłego Dziecka Alkoholika jest niska samoocena, z którą bohater próbuje sobie radzić, obnosząc się ostentacyjnie (i boleśnie) ze swoim pochodzeniem. W Luwrze, centrum kultury europejskiej, pośród dzieł wielkiej sztuki, podczas spotkania z wysoko urodzonymi rodaczkami swoje „koligacje” przedstawi brutalnie i bez osłonek:

Ja pochodzę z Warszawy, z samej Warszawy. I z bardzo byle jakich Judymów... [...]

- Ojciec mój był szewcem, a w dodatku lichym szewcem na Ciepłej ulicy. Na Ciepłej ulicy... - powtórzył z kłującą satysfakcją. Uniknął wreszcie chwiejnego gruntu i grzecznych delikatności, w czym nie był mocny i czego się w przesadny sposób obawiał (14). 
W taki sposób Judym oswaja lęk i wstyd. Mocne, jednoznaczne wyznanie pozwala mu zająć w towarzystwie stosowne miejsce, ostatnie miejsce, z którego nikt go już nie będzie mógł wyrugować. Na samym wstępie przyznaje się do swego plebejskiego pochodzenia asocjującego przysłowiową profesję ojca i asekuruje się przed ewentualną demaskacją: niedostatecznym obyciem w wielkim świecie konwenansów przejawiającym się w obyczajach i konwersacji, nawet erudycji.

Typowym objawem DDA jest niemożność nawiązania partnerskich relacji. Bohater pragnie ich, ale jednocześnie boi się je utracić:

[...] ciągle płynęły w jego sercu dwie strugi: tęsknota i trwoga. Gdy przypatrywał się wykwintnej i delikatnej postaci panny Joasi, stawała mu w oczach, jak nieodłączne widmo, suterena z ulicy Ciepłej. Wszystko zdobyte znikało. Pamiętał o swojej rodzinie rzemieślniczej, o ciotce, która go wychowała, o towarzyszach jej zabaw... Zdawało mu się, że skulony, obdarty, głodny i zdeptany, stojący na samym brzegu upodlenia, jest w ciemnej izbie piwnicznej. I oto zstępuje po schodach ciemna osoba. Słychać cichy szelest jej sukien, pachnący szmer jej nadejścia... Zwolna schodzi, zatrzymuje się na każdym głazie. Niesie w oczach dalekowidzących przedziwne posłannictwo swojej miłości (301).

Wyobrażenia (lub sny) o ciemnej piwnicy czy lochach są typowe dla dzieci z zespołem DDA. Umiejscowienie siebie poniżej innych jest symptomem niższości, mroczne miejsce - lęku i wstydu. Judym cierpi na dojmujący kompleks niższości i w głowie nie chce mu się pomieścić, by on, budzący odrazę syn szewca z Ciepłej, mógł być kochany, sądzi, że miłość do niego jest jakąś osobliwą misją Joanny, jej samoponiżeniem. Judym nie ma ani zaobserwowanego, ani wyobrażonego obrazu mężczyzny. Nie wie, jakim powinien być on sam, nie widzi się ani w roli męża, ani w roli ojca. Nie myśli o Podborskiej jako o kochance, nigdy nie pożąda jej ciała i, mimo rodzącego się między nimi zrozumienia, rozstaje się $\mathrm{z}$ nią. Utrwalona $\mathrm{w}$ literaturoznawstwie interpretacja tego rozstania jako konsekwencji powziętej przez bohatera decyzji o misji, która wymaga ofiar, a przede wszystkim rezygnacji z prywatności, wymaga rewizji w kontekście problemu DDA, z którym zmaga się Judym. Nie należy więc zapominać o spontanicznej reakcji Podborskiej, kiedy w pałacu wersalskim wcieliła się mimo woli w rolę Marii Antoniny:

Judym [...] przypatrzył się pannie Joannie. Stała oparta o jedno z niewielkich krzeseł, kryte nikłym błękitnawym adamaszkiem, i patrzyła w okno. Wyraz twarzy jej był tak dziwny, że Judym wstrzymał się mimo woli. Później zbliżył się do niej [...]: - Myśli pani o Marii Antoninie?

Spojrzała na niego z zakłopotaniem, jak osoba ujęta na gorącym uczynku, i wahającym się głosem mówiła: 
- Widać stąd, przez to okno, wielki dziedziniec i bramę. Tamtędy... Tamtędy wdarł się motłoch. Pijane kobiety, mężczyźni uzbrojeni w noże. Maria Antonina widziała z tego okna! Doznałam tak dziwnego wrażenia... Cały ten straszny tłum krzyczał: „Śmierć Austriaczce!’. I tędy, tymi drzwiami uciekła, tędy uciekła...

- Wspomniałam o wrażeniu... - mówiła spuszczając oczy i blednąc jeszcze bardziej. - My, proszę pana, jesteśmy bardzo tchórzliwe. Boimy się nie tylko na jawie, ale i w tak zwanych marzeniach. Ja zlękłam się bardzo tego motłochu, o którym właśnie myślałam.

- Motłochu? - mówił Judym.

- Tak...To jest krzyku ich. Zlękłam się, sama nie wiem, czegoś takiego... (31-32; podkr. - D.S.K.).

Czy zatem kobieta, która swój ,zmysł udziału” dzieli nie z ludem, a z królową (dającą wyraz własnej świadomości społecznej w zapamiętanej przez dzieje, nieironicznej przecież ripoście: „Jeśli tłum nie ma chleba, niech je ciastka”) i która nędzarzy nazywa motłochem, może dzielić życie z człowiekiem z tego motłochu pochodzącym i temu motłochowi z wyboru służącym? Echa wersalskich słów Podborskiej odezwą się przecież w Judymowej pamięci w drodze do Zagłębia, ostatniej stacji jego krzyżowej drogi misjonarza:

Była to lecznica. Stał tam tłumek ludzi szarych: jeden z okiem szmatą zawiązanym, drugi z ręką w grubym bandażu, inny z fizjonomią wyrażającą silny ból na wnątrzu. Judym widział ich wszystkich jakby przez deszcz ulewny. Myśl o tym, że może mu przyjdzie leczyć tych ludzi, zajmować się ich cierpieniami, była mu tak wstrętną jak samo cierpienie. Zastanawiał się nad tym, że niegdyś słyszał od kogoś wyraz: - motłoch. Od kogo mianowicie?... Od kogo? Zachodził w głowę, męczył się, był tuż, tuż obok zjawiska, obok wszelkich okoliczności, które towarzyszyły temu zdarzeniu... Po długich wysiłkach znalazł się w Wersalu w pokoikach Marii Antoniny i usłyszał ten wyraz z ust Joasi. Jak dobrze, jak zupełnie to słowo malowało istotę rzeczy! (334-335).

Przyznanie racji Joannie jest kolejnym samoudręczeniem Judyma. Wykształcony, wypolerowany przez obcowanie z wyższą kulturą, zaczyna brzydzić się tymi, którym zamierza się całkowicie poświęcić. Zaczyna rozumieć swoją nieszczerość, nieuczciwość wewnętrzną, przymus. Samotność z wyboru jest sposobem uniknięcia wstydliwych sytuacji walki z samym sobą, którym świadkować musiałaby osoba bliska, a także rodzajem zabezpieczenia przed cierpieniem rozstania, które kiedyś w końcu musiałoby nadejść, wszak on, Tomasz Judym z Ciepłej, nie może być kochany, nie może być szczęśliwy. Judym woli odejść, zanim relacje z Podborską nie wkroczą w jego najgłębiej skrywaną intymność. Zanim Joanna zostanie skrzywdzona. Zanim w końcu da mu odczuć swoją wyższość 
i politowanie. Tak przecież musi się kiedyś stać, bo Judym jest mistrzem w negatywnym i pesymistycznym ocenianiu siebie. Dlatego odstręcza ją, tłumacząc:

- Widzisz... Ja jestem z motłochu, z ostatniej hołoty. Ty nie możesz mieć wyobrażenia, jaki jest motłoch. Nie możesz nawet objąć tego dalekim przeczuciem, co leży w jego sercu. Jesteś z innej kasty... Kto sam z tego pochodzi, kto przeżył wszystko, wie wszystko... Tu ludzie w trzydziestym roku życia umierają, bo już są starcami. Dzieci ich - to idioci.

- Ale cóż to ma do nas?

- Przecie to ja jestem za to wszystko odpowiedzialny! Ja jestem!

- Ty... odpowiedzialny?

- Tak! Jestem odpowiedzialny przed moim duchem, który we mnie woła: „nie pozwalam!"

Jeżeli tego nie zrobię ja, lekarz, to któż to uczyni? Tego nikt...

- Tylko ty jeden?

- Otrzymałem wszystko, co potrzeba... Muszę to oddać, com wziął. Ten dług przeklęty... Nie mogę mieć ani ojca, ani matki, ani żony, ani jednej rzeczy, którą bym przycisnął do serca z miłością, dopóki z oblicza ziemi nie znikną te podłe zmory. Muszę wyrzec się szczęścia. Muszę być sam jeden. Żeby obok mnie nikt nie był, nikt mię nie trzymał! (402-402).

Nie tyle brak wzorca małżeńskiego, ile raczej jego utrwalony w pamięci bohatera paradygmat - wykoślawiony i zdeformowany przez ojcowski nałóg i matczyną zgryzotę - staje się zakazem wchodzenia w układ, który może w przyszłości stać się w jakimś sensie powtórzeniem lub konfiguracją tamtego. Wzniosłe ideały, w które wierzy Judym i które w tak patetyczny sposób przed Joanną rozwija, są mało przekonujące, zwłaszcza że w ich realizacji bohater poniósł już niejedną klęskę. Wydaje się raczej, że służą mu za pretekst do rozstania, aby cierpieć tym mocniej, gdy znajdzie się w sytuacji odrzucenia i nieszczęścia.

Ponadto doświadczenia wyniesione $\mathrm{z}$ domu ciotki, upokarzające go wówczas i później, wraz z narastaniem świadomości, że to za pieniądze z jej profesji został lekarzem, przygniatają go poczuciem własnej podrzędności:

[...] pierwszych lat byłem na posyłkach, froterowałem, czyściłem posadzki, myłem w kuchni garnki, rondle, nastawiałem samowary i latałem, latałem bez końca za sprawunkami. Jeszcze dz m pamiętam ten dom, te schody kuchenne! Ile ja tam cierpień... Sypiałem zawsze w przedpokoju, na sienniku, który wolno mi było przywlec z ciemnego pasażyka za pokojem ciotki wówczas dopiero, gdy się już wszyscy goście od niej wynieśli. Kładłem się spać późno w nocy, a wstawać musiałem najwcześniej ze wszystkich. [...] Wstawać musiałem, gdy jeszcze wszyscy spali. Prał mię, kto chciał: ciotka, służąca, lokatorowie, nawet stróż w bramie wlepiał mi, jeśli nie kułaka w ple- 
cy, to przynajmniej słowo, często twardsze od pięści. I nie było apelacji. Moje lekcje [...] odrabiałem w kuchni, na stole zawalonym rondlami, wpośród ziemniaków i masła. Ileż to razy ciotka mię wyganiała precz, za byle winę! Ile razy musiałem błagać na klęczkach, żeby mię znowu przyjęła do swego „domu”! Czasami w przystępie świetnego humoru dawała mi swoje rozklapane trzewiki, w których ku szczerej radości całego gimnazjum chodzić musiałem. Trafiła się zima, kiedy się w prunelowych pantoflach z wysokimi obcasami, albo inna, w której całym ciągu mogłeś był widzieć na śniegu ślad moich bosych nóg, choć niby to były okryte przyszwami. [...] Ale całe moje dzieciństwo, cała pierwsza młodość upłynęły w nieopisanym, wiecznym przestrachu, w głuchej nędzy, którą teraz dopiero pojmuję (56-57).

Trudno Judymowi oddzielić się od siebie samego z tamtych lat, zbyt bolesne to doznania, by móc je wyprzeć z pamięci tak, by nie utożsamiać się z nimi. Obraz siebie jako poniewieranego i wyśmiewanego chłopca do bicia obutego w damskie pantofle jest jak stygmat. Brak stabilnej, jednorodnej tożsamości, brak poczucia bezpieczeństwa oraz brak nadziei na zmianę myślenia o sobie jako o niepełnowartościowym człowieku i partnerze, a taka zmiana nie dokonuje się wszak z upływem lat, stają się powodem ostatecznej decyzji. Bez kontekstu psychologicznego trudno tę decyzję motywować. Rację ma Henryk Markiewicz, który nazywa ją „,hiperostrożną profilaktyką moralną, całkowicie niepotrzebną wobec osoby takiej jak Joasia"11. Gdy podczas ostatniej rozmowy roztacza ona przed Judymem wizję szczęśliwego stadła, narzucając mu swój, kobiecy punkt widzenia, pełen miękkości i delikatności, czytelnik już przeczuwa, że zapał Podborskiej zostanie szybko zgaszony, a jej plany obrócą się w niwecz. Judym wybierze samotność, potrzebną mu najpierw do przepracowania swego nieszczęścia, a potem: albo do nauczenia się samego siebie od nowa, albo do samounicestwienia.

Epizod ze „swawolnym Dyziem”, najbardziej - wydawałoby się - luźnym, niemal stanowiącym osobny tekst fragmentem Ludzi bezdomnych, ma ukazać odbiorcy stosunek Judyma do dzieci. Wprawdzie Dyzio cierpi zapewne na ADHD, a jego zachowania przekraczają wszelkie normy dobrego wychowania, których nie wpoiła mu bezwolna matka ${ }^{12}$, niemniej postawa Judyma wobec swawoli chłopca daje wiele do myślenia. Najpierw bowiem Judym powstrzymuje się od wszelkiej reakcji wobec coraz śmielszych zaczepek dziecka, unika wszelkiej, a zwłaszcza słownej perswazji, gdy jednak eskalacja dokuczliwości osiąga wymiar nieledwie groteskowy i nie da się już ukryć, że Judym - zapewne wskutek swej bierności - stał się ofiarą małego łobuza, bohater ucieka się do wymierzenia sprawiedliwości:

${ }^{11}$ H. Markiewicz, Prus i Żeromski. Rozprawy i szkice literackie, Państwowy Instytut Wydawniczy, Warszawa 1954, s. 218.

${ }^{12}$ Ciekawe studium osobowości „sowizdrzała” Dyzia daje M. Jonca, Enfants terribles: dzieci złe, źle wychowane w literaturze polskiej XIX wieku, Wydawnictwo Uniwersytetu Wrocławskiego 2005, s. 392-395. 
serii klapsów. Nieumiejętność nawiązania kontaktu z dzieckiem, brak spontaniczności i skrępowanie w tak jednoznacznej sytuacji dają do myślenia. Judym, jak większość DDA, nie zamierza mieć dzieci, dzieciństwo bowiem kojarzy mu się z udręką i wstydem, siebie samego z tamtych lat pamięta jako kogoś, kto godny był politowania i pogardy. Będąc ojcem, mimowolnie musiałby wejść w przestrzeń relacji, z których go niegdyś w bolesny sposób ograbiono. Zabór dzieciństwa przez ojca alkoholika to okaleczenie na całe życie, dojrzewanie w domu schadzek to rana nie do zagojenia.

W rozdziale zatytułowanym znacząco i ironicznie: Szewska pasja ujawnia się jeszcze inny rys osobowości Judyma jako DDA - agresja.

Judym dostrzegł ten ruch i stracił świat z oczu. Jednym susem przypadł do Krzywosąda, chwycił go za gardziel, targnął nim z dziesięć razy, a potem pchnął go od siebie. Administrator stał tyłem do stawu. Rzucony przez Judyma, zleciał z grobli, runął w szlam i zanurzył się w rzadkie bagno [...]. Judym nie widział, co było dalej. Oczy mu zaszły wściekłością, jak bielmem. Szedł drogą klnąc głośno, ordynarnie... (314)

Bójka, w której napastnikiem uciekającym się do rękoczynów jest Judym, wynika wprawdzie z czynnika szlachetnego, wszak bohater walczy o dobro mieszkańców okolic cisowskich, ale zasadniczą i bezpośrednią przyczyną gwałtownej reakcji Judyma jest cyniczno-szyderczy doń stosunek Krzywosąda. Najpierw bowiem obaj z dyrektorem lekceważą obecność Judyma, kiedy dojdzie zaś do utarczki słownej, a w wypowiedziach adwersarzy odezwą się tony wyższości i pobłażania dla Judymowej naiwności, ten, rozzłoszczony do granic możliwości, swego przeciwnika pobije i wrzuci do stawu. Judym działa spontanicznie, emocjonalnie, nie myśli o konsekwencjach. Agresja jest prostą reakcją na wstrętne, upokarzające go traktowanie.

Judym - jak Golemowski Charousek - jest lekarzem. Wydawałoby się, że osiągnął sukces, że poprzez wykształcenie uwolnił się od „szewstwa” ojca, że przezwyciężył prymitywizm myślenia motłochu warszawskiego śródmieścia, gdzie tkwią jego korzenie. Ekstyrpacja jest jednak niemożliwa, upiory przeszłości nie dają zapomnieć o doświadczeniach, które odżywają wraz z najdrobniejszymi przypomnieniami i asocjacjami, są jak echo dawnych dni, niby przebrzmiałe, ale wciąż gotowe do ataku ${ }^{13}$. Wrośnięty w Judyma kompleks niższości, chwiejna wiara we własne możliwości, niepewność i obawa przed kompromitacją są skutkiem tragicznego, ponurego dzieciństwa pośród patologii społecznych i brudu

${ }^{13}$ Pisze o tym M. Popiel (Oblicza wzniosłości. Estetyka powieści młodopolskiej, Universitas, Kraków 2003, s. 91-92), stan pamięci Judyma nazywając kryptomnezją (pamięcią utajoną) i opierając swoje rozważania na badaniach Edwarda Abramowskiego. 
moralnego. Dlatego Judym czuje się trędowaty, chory na nieuleczalną chorobę, której nie zaradzi żaden lek. To choroba na wstręt do własnej krwi odziedziczonej po znienawidzonym ojcu.

\section{Eksperiencja wstrętu}

Nie jest rzeczą przypadku, że czytelnik poznaje Tomasza Judyma w paryskim Luwrze, gdzie udaje się po raz pierwszy, walcząc ze swoim kompleksem niższości: „Dlaczegóż, u licha, nie miałbym pójść do tego Luwru?...” (5). Kontemplacja posągu Wenus z Milo zapowiada estetyczne upodobania Judyma: pociąg do piękna wyrafinowanego (także kobiecego ciała), potrzebę luksusu, tęsknotę do szczęścia ${ }^{14}$. Ujawniają się przy tym aż dwie sprzeczności: plebejski rodowód, dzieciństwo i dojrzewanie w aurze brzydoty i nędzy oraz wybór zawodu wiążącego się z przygnębiającą codziennością choroby i śmierci. Jakby wbrew sobie, wbrew swemu wybujałemu sensualizmowi oraz naturalnej wrażliwości na piękno i jego pożądaniu ${ }^{15}$, decyduje się opuścić Paryż i powrócić do Warszawy. Rozstaje się z Wenus i jako alegorię swojego losu przyjmuje Biednego rybaka (Puvisa de Chavannesa):

Widział go przed rokiem i uderzony niewypowiedzianą siłą tego arcydzieła zachował je w pamięci. Z czasem wszystko, co stanowi samo malowidło, szczególną rozwiewność barw, rysunek figur i pejzażu, prostotę środków i całą jakby fabułę utworu, przywaliły inne rzeczy i zostało tylko czujące wiedzenie o czymś nad wszelki wyraz bolesnym. Wspomnienie owo było jak mętne echo czyjejś krzywdy, jakiejś hańby bezprzykładnej, której nie byliśmy winni, a która przecie zdaje się wołać na nas z ziemi dlatego tylko, że byliśmy jej świadkami (25).

${ }^{14}$ Dyskusyjna wydaje się teza A. Zdanowicz (Metafizyka i życie społeczne. Stefan Żeromski wobec problemów współczesności, Instytut Książki i Czytelnictwa, Warszawa 2005, s. 120), która pisze: Judym ,nie zwraca uwagi na dzieła sztuki, trzeba wyjątkowych okoliczności, by pobudziły go one do refleksji” i dalej: „Kultura sfer wyższych kojarzy mu się nieodparcie z wyrafinowaną zmysłowością i tym jedynie go pociąga”. Przeczy temu wiele ustępów Ludzi bezdomnych, choćby epizod z Biednym rybakiem, obrazem, który Judym poznał i ocenił, zanim z ust Joanny padło pytanie o jego ocenę. Obcowanie ze sztuką wydaje się dla Judyma „zwiewnym kontaktem - nacechowanym rozkoszą, a jednocześnie niezagrożonym sankcjami - z ciemnym kontynentem odrzucanych i wypieranych impulsów" - W. Menninghaus, Wstręt-teoria i historia, przeł. G. Sowiński, Universitas, Kraków 2009, s. 280.

${ }^{15}$ Co wynika nie tylko z fabuły, ale także z samej narracji, w której Judym pełni niekiedy funkcję tzw. „bohatera prowadzącego”, zob. M. Głowiński, Powieść młodopolska. Studium z poetyki historycznej, Universitas, Kraków 1997, s. 116-117. 
Litość i gniew na niesprawiedliwość każą Judymowi wybrać nie piękno, ale obowiązek, który sam sobie narzuca tylko dlatego, że jako dziecko był świadkiem ludzkich krzywd, teraz zaś tym krzywdom może zaradzić. W postanowieniu będzie trwał aż do końca, albowiem imperatyw wewnętrzny, głęboka wrażliwość i szerokie serce nie pozwolą mu nigdy zboczyć z obranej drogi. Maksymalizm etyczny bohatera nakazuje mu ograniczenia. O kontemplacji piękna i osobistym szczęściu musi zapomnieć. A jest to trudne zadanie. Żądająca wyłączności posługa lekarska, walka ze środowiskami, a także z ludzką nieufnością i niedowierzaniem w jego najlepsze intencje, okazują się drogą przez mękę.

Już powrót do Warszawy przynosi rozczarowanie ${ }^{16}$. Początkowy entuzjazm „bycia u siebie”, zrodzony z doraźnego dobrego samopoczucia i idealizującego wyobrażenia (,żywy i słodki zapach pól rodzinnych"), zamienia się we wstrę ${ }^{17}$ pod wpływem odpychających doznań zmysłowych podczas wędrówki na Ciepłą, gdzie „wydzielał się fetor jak z cmentarza”, stały „mury w kolorze zakurzonego grynszpanu albo jakiejś zrudziałej czerwoności, niby pstre, ubłocone gałgany", „chodniki były jak niegdyś zdruzgotane, bruk pełen wądołów”, „roiło się [...] mrowisko żydowskie", „włóczyli się roznosiciele wody sodowej z naczyniami u boku i szklankami w rękach. Sam widok takiej szklanki oblepionej zaschłym syropem, którą brudny nędzarz trzyma w ręce, mógł wywołać torsje". W mijanych po drodze sklepikach ,czerniała na podłodze kupa błota [...], po tym gnoju pełzały dzieci okryte brudnymi łachmany i same brudne nad wyraz", tu i ówdzie „widać było warsztat szewski, ciemną pieczarę, z której wywalał się smród namacalny”, w zakładach fryzjerskich ,blade, żółte, obumarłe dziewczyny, same nie czesane ani myte, pracowicie rozdzielały kłaki', z okien domów zaś „wychylały się twarze chore, chude, długonose, zielone, moręgowate i patrzały oczy krwawe, ciekące”. Nic dziwnego, że „Judym szedł prędko, mrucząc coś do siebie”, a do rodzinnej kamienicy zbliżył się „,z niemiłym uczuciem tak zwanego «fałszywego wstydu»”. I tam przywitała go „sień brudna jak apartament Lucypera”, „czeluść otwarta, prowadzącą do rodzinnej sutereny”. Metaforyzacja infernalna wyraźnie sugeruje odpychającą, a nawet przerażającą repulsywność wrażeń. Spotkanie z rodziną dostarcza Judymowi „nieprzyjemnego uczucia półodrazy, zbudzonej i wydobytej na jaw przez szczególne politowanie, stanowiące rdzeń uczuć familijnych" (35-40).

\footnotetext{
${ }^{16}$ M. Popiel (dz. cyt., s. 95) nazywa ten moment „dramatycznym sprzężeniem utożsamienia i obcości”. Badaczka słusznie zauważa, że wędrówka Judyma „do siebie” nie jest ani sentymentalną podróżą do dzieciństwa, ani „współczującym przeżywaniem nędzy” (s. 96) warszawskiej biedoty.

${ }^{17} \mathrm{Na}$ obrzydzenie, a jednocześnie grozę wywołaną w Judymie „nędzą bytowania” mas ludzkości z warszawskiego śródmieścia zwraca na to uwagę H. Janaszek-Ivaničkova, Świat jako zadanie inteligencji. Studium o Stefanie Żeromskim, Instytut Badań Literackich PAN, Warszawa 1971, s. 102. Badaczka nie interpretuje jednak tej kwestii z puntu widzenia estetyki, skupiając się wyłącznie na moralnym wymiarze Judymowych refleksji.
} 
Obrzydzenie „mikroojczyzną”, coraz mocniej odczuwany wstręt do detali przestrzennych (miejsc, przedmiotów, ludzi) spowodowane są prawdziwą synestezją wrażeń zmysłowych. Zachowanie Judyma świadczy o tym, że wkroczenie w sam środek odrażającego świata wyprowadza go z równowagi, że przybycie tam - z moralnego obowiązku i z pozytywnym nastawieniem (trudno dociec, czego się właściwie Judym spodziewał) - jest działaniem, które go przerasta. Pragnienie dystansu, ucieczki zdominuje tę "sentymentalną" peregrynację ${ }^{18}$. Stricte naturalistyczne opisy „pejzażu” z ekspozycją nieczystości, choroby, ułomności, o kolorystyce asocjującej rozkład i wszechobecną lepkość (tłuszczu, błota etc.), o zapachach przyprawiających o zawrót głowy współgrają z nastrojem bohatera, który przyszedł na rekonesans swojego „miejsca pracy”.

Judym z całej mocy charakteru nie chce żałować decyzji o powrocie, ale rozczarowanie i obrzydzenie wypływają z niego mimochodem. Ich źródłem jest awersja do brzydoty, ułomności, wstręt do ludzkich mas ${ }^{19}$. O ile nieestetyczność jako stygmat nędzy smutnych, ubogich ludzi na obrazie Chavannesa budziła współczucie, o tyle w rzeczywistości staje się nie do zniesienia; nie wywołuje litości, ale politowanie i obrzydzenie, w konsekwencji także lęk przed bliskością:

O zmierzchu Judym wyszedł z ogrodu w stronę placu Teatralnego. Gdy zapalono latarnie, był na Bankowym. Jaskrawy blask rewerberu padł właśnie na chodnik prowadzący w kierunku ulicy Elektoralnej. W świetle tym widać było fale ludzi spływające bezustannie za ciemną sylwetkę banku jakby w szyję naczynia. Judym stanął. Te czarne masy głów i tułowiów, sunące prędko niby mrówki, zbudziły w nim uczucie fizycznej odrazy. Zdawało mu się, że spogląda na sunące ławy robactwa. Wmieszać się w motłoch mieszkający tam, za tym placem - przenigdy! Przenigdy! Zawrócił na miejscu z mocnym postanowieniem zobaczenia się z bratem kiedy indziej - i wszedł do wykwintnej restauracji (51).

Wykwintna restauracja staje się więc remedium na wstręt, jaki wywołuje tłum warszawskiej biedoty, nieprzypadkowo przez Judyma animalizowany. Odhumanizowana masa poruszająca się ruchem jednostajnym kojarzy się patrzącemu z czarnym robactwem, jednym z najsilniejszych bodźców wzbudzających powszechne obrzydzenie. Myśl o fizycznym kontakcie z tą masą przeraża, budzi tak wielki wstręt, że wstrzymuje bohatera przed zobaczeniem się po długiej rozłące z rodzonym bratem. Kiedy w końcu nazajutrz Judym decyduje się do niego pójść, czyni to ze wstrętem, przeciw któremu nie jest w stanie się uzbroić.

${ }^{18}$ Rozważania o wściekłości i pragnieniu dystansu wobec przedmiotów wstrętnych zob. S. Ahmed, Performatywność obrzydzenia, przeł. A. Barcz, „Teksty Drugie” 2014, z. 1, s. 174.

${ }^{19}$ Wstręt Judyma do motłochu E. Ihantowicz (dz. cyt., s. 66-67) nazywa bardziej subtelnie - ,antypatią za ordynarność duchową". 
To samo uczucie odrazy powróci w Cisach, gdy Judym dowie się o planach Joanny mającej zamiar pomagać ludziom chorym na malarię. Judym nie chce widzieć kobiety, którą kocha, w roli pielęgniarki nieestetycznie chorych; zatrudnienie takie - choć całkowicie zgodne z jego misją - wzbudza w nim niesmak. Już te doznania powinny były Judymowi uzmysłowić niemożność powrotu, nierealizowalność zadania, jakie przed sobą postawił. Wszak uczucie wstrętu - jako nieprzyjemne - zmusza do ucieczki przed nim, wyzwolenia z przykrej sytuacji. Więcej: według badań naukowych obrzydzenie nie tylko potęguje negatywne emocje, rozdrażnienie i zniechęcenie, ale wywołuje zachowania nieetyczne, co w przypadku lekarza jest tym bardziej niebezpieczne.

Obraz Judyma jako „sosny rozdartej”, którą zniekształciły czynniki zewnętrzne, jest przeraźliwie smutny, smutniejszy aniżeli postać rybaka z obrazu Chavannesa. I choć Żeromski zawiesza głos, pejzaż mentalny bohatera o rozwarstwionej naturze, zawieszonego między niebem i ziemią, nie zapowiada zmiany. Czytelnik rozstaje się z Judymem pozostającym w bezruchu, kontemplującym naturę w jej zdeformowanym detalu:

Pień jej stał jedną połową swoją w górze, a drugą szedł wraz z zawaliskiem, niby istota ludzka, którą na pal wbito. Tamten, z bryłami ziemi w dół ściągnięty, prężył się jak członki na torturach. Wszczepione w glebę pazury górne trzymały się z całej siły. Judym zsunął się w zawalisko, żeby go nikt nie widział. Rzucił się na wznak. Pod sobą w głębi ziemi słyszał od czasu do czasu huk wystrzałów dynamitu i prochu. W górze widział obłoki sunące po niebie lazurowym (405).

Zastygnięcie Judyma w kopalnianej rozpadlinie, słyszącego pod sobą huki wystrzałów i widzącego lazurowe niebo to znak wyboru, którego bohater nigdy nie dokona. To zawieszenie pomiędzy niebem, to jest „urodą życia”, a czeluściami ziemi, to jest twardym obowiązkiem (,,jestem odpowiedzialny przed moim duchem, który we mnie woła: «nie pozwalam!»), stanowi symbol ponawianego - zrazu epizodycznie, w miarę zaś upływu czasu coraz częściej - procesu psychomachii i stopniowego polaryzowania się osobowości Judyma ${ }^{20}$. Nazbyt dotkliwe

\footnotetext{
${ }^{20}$ Przywołany passus odsyła także do Lalki, co nie dziwi, zważywszy na powinowactwa powieści, rodzaj polemiki Żeromskiego z Prusem. Mimo że oba utwory wydane zostały w zasadzie w jednym dziesięcioleciu, są reprezentacją innych czasów, zarówno pod względem przesłań duchowych, jak i formy powieściowej. Wyraźne paralele świadczą jednak o celowym zabiegu usytuowania Ludzi bezdomnych wobec Lalki. Wokulski i Judym to ludzie zaplątani w przeszłość, uwikłani emocjonalnie w jej sidła, ludzie bez stabilnej, wspartej na solidnym gruncie tożsamości, mający problemy z odnalezieniem swojej roli i swego miejsca. O ile jednak bohater Lalki
} 
obciążenie traumą pogmatwanego dzieciństwa, silny sprzeciw wobec pochodzenia i odziedziczonych genów, z drugiej zaś strony szlif edukacyjny i skłonność do kontemplacji piękna, a nade wszystko samoświadomość, czynią życie Judyma nieznośnym i pełnym sprzeczności, z którymi, także jako lekarz, nie potrafi się pogodzić. Judym to człowiek, który w poszukiwaniu tożsamości chciał przekroczyć samego siebie. To wykoncypowany idealista, który chciał być self-made manem. Za wszelką cenę chciał uwolnić się od ojca mentalnie, ale ojcobójstwo uważał za najcięższy grzech ${ }^{21}$. Gdyby - jak Charousek - poszedł na grób ojca, może odnalazłby sposób na ostateczne uformowanie tożsamości albo jej... ostateczne zatracenie.

\section{Bibliografia}

Ahmed Sara, Performatywność obrzydzenia, przeł. A. Barcz, „Teksty Drugie” 2014, z. 1, s. 169-191. Eile Stanisław, Alogiczność i przypadek w prozie Żeromskiego, „Pamiętnik Literacki” 1976, z. 1, s. $3-13$.

Gelbin Cathy S., The Golem returns. From German romantic literature to global Jewish Culture 1808-2008, University of Michigan, 2011.

Głowiński Michał, Powieść młodopolska. Studium z poetyki historycznej, Universitas, Kraków 1997.

Ihnatowicz Ewa, Bohaterowie współczesnej polskiej prozy współczesnej 1864-1914. Artyści, twórcy, Wydawnictwo Uniwersytetu Warszawskiego, 1999.

Janaszek-Ivaničkova Hanna, Świat jako zadanie inteligencji. Studium o Stefanie Żeromskim, Instytut Badań Literackich PAN, Warszawa 1971.

Jonca Magdalena, Enfants terribles: dzieci złe, źle wychowane w literaturze polskiej XIX wieku, Wydawnictwo Uniwersytetu Wrocławskiego 2005.

Kristeva Julia, Potęga obrzydzenia. Esej o wstręcie, przeł. M. Falski, Wydawnictwo Uniwersytetu Jagiellońskiego, Kraków 2007.

Markiewicz Henryk, Prus i Żeromski. Rozprawy i szkice literackie, Państwowy Instytut Wydawniczy, Warszawa 1954.

Menninghaus Winfried, Wstręt-teoria i historia, przeł. G. Sowiński, Universitas, Kraków 2009.

Meyrink Gustav, Golem, przeł. A. Lange, Skład Główny w Księgarni F. Hoesicka, Warszawa 1919.

Mitchell Mike, Vivo: The Life of Gustav Meyrink, Dedalus, Cambs 2008.

Popiel Magdalena, Oblicza wzniosłości. Estetyka powieści młodopolskiej, Universitas, Kraków 2003.

Tokarska-Bakir Joanna, Legendy o krwi. Antropologia przesadu, WAB, Warszawa 2008.

Wegscheider-Cruse Sharon, Nowa szansa, przeł. M. Ślósarska, Instytut Psychologii Zdrowia, Warszawa 2000.

pada ofiarą złudzeń i romantycznych mitów, uniemożliwiających mu trzeźwą ocenę sytuacji, oraz hybris, która każe mu „widzieć się trochę lepszym od innych”, Judym ma problem z gminnym rodowodem, z ojcem pijakiem, z motłochem jako jego ludzką ojczyzną. Domniemane wysadzenie się Wokulskiego w zasławskiej studni w ruinach romantycznych to sygnał, który rozumieć należy jako ostateczne połączenie się bohatera z przeszłością.

${ }^{21} \mathrm{O}$ czym świadczy rozmowa z Korzeckim (rozdz. Dajmonion, s. 380). 
Woititz Janet K., Dorosłe dzieci alkoholików, przeł. M. Winkler, Wydawnictwo Akuracik, Warszawa 1992.

Zdanowicz Anna, Metafizyka i życie społeczne. Stefan Żeromski wobec problemów wspótczesności, Instytut Książki i Czytelnictwa, Warszawa 2005.

Zieniewicz Andrzej, Dorosłe Dzieci Epoki. Codzienność utajona w prozie lat dziewięćdziesiatych, w: Codzienne, przedmiotowe, cielesne. Języki nowej wrażliwości w literaturze polskiej $X X$ wieku, red. H. Gosk, Świat Literacki, Izabelin 2002, s. 67-85.

Żeromski Stefan, Ludzie bezdomni, oprac. I. Maciejewska, Zakład Narodowy im. Ossolińskich, Wrocław 1987.

\section{Dorota Samborska-Kukuć}

\section{Charousek's syndrome. Tomasz Judym's Problems with Identity}

\section{(Summary)}

In literary studies, Judym, the protagonist of Ludzie bezdomni, is usually treated as a social activist fixated on the mission to improve the world. However, such interpretation is not exhaustive because the character's behaviour, not always rational and sensible, is a result of his beliefs and worldview. His identity problems, which pose the principal difficulty for him and which are the driving force of his actions, are rooted in his inferiority complex, born and developed on the foundation of his dysfunctional upbringing with an alcoholic father and later his aunt, a prostitute. Aversion to his familial heritage makes Judym a profoundly emotionally repressed man, unable to cope with life and emotional relationships. Understanding these difficulties helps readers to see the character's alienation and motivations, which he would like to be considered as "paying the debt" he owes to the social group from which he came.

Słowa kluczowe: Stefan Żeromski; Ludzie bezdomni; Gustav Meyrink,; Golem; syndrom DDA

Keywords: Stefan Żeromski; Ludzie bezdomni; Gustav Meyrink; Golem; ACoA syndrome 